\title{
Tax Regulation of Activity of Agricultural Commodity Producers
}

\author{
Khafizova A.R. \\ Kazan Federal University, Institute of Management, Economics and Finance, Kazan, 420008, Russia
}

Galimardanova Yu.M.

Kazan Federal University, Institute of Management, Economics and Finance, Kazan, 420008, Russia

Salmina S.V.

Kazan Federal University, Institute of Management, Economics and Finance, Kazan, 420008, Russia

Email address: hafiwka@mail.ru

\section{Doi:10.5901/mjss.2014.v5n24p421}

\begin{abstract}
The article is devoted to the current problems of tax regulation in the field of agricultural production in the Republic of Tatarstan and necessity of solving them. In our opinion, improvement of tax regulation of agricultural production in the Republic of Tatarstan should be carried out by means of development of effective mechanisms of tax regulation of activity of agricultural commodity producers of the Republic of Tatarstan, which in turn, would promote its further dynamic development.
\end{abstract}

Keywords: agricultural production, agricultural commodity producer, taxation, tax regulation, unified agricultural tax.

\section{Introduction}

Agriculture, providing satisfaction of needs of the population for the foodstuffs, takes an important place in economic system of the state. Today, agricultural production and distribution system is becoming more and more interdependent, integration and globalization. Two major themes in the direction of agricultural products around the world today, include ensuring the safety and improve the quality [1]. Recently, the critical issues of food security and rising food prices have led the development of the concept of multifunctional agriculture, food security and socio-economic and environmental sustainability to the forefront of agricultural policy [2]. It is generally believed that trade liberalization results in a less stringent environmental standards, which suggests that the policy of regulation of trade and the environment are positively correlated [3]. Effective development of agricultural sector of economy of Russia depends not only on natural and climatic conditions, but also on support from the state in the form of creation of favorable economic conditions of management. Now agricultural production is one of the major and dynamically developing branches of domestic economy, it is shown in the main financial performance of development of this branch in the Republic.

Tax regulation, being the most important instrument of state administration, can influence the development of national economy of the country and its separate branches, including means of support and ensuring financial stability of development of agricultural production. Transition to the innovative model of development has become a fait accompli in many developed countries. As international experience shows any state is able to be one of the leading economies due to comprehensive innovative development even without having abundant natural resources reserve [4]. This also applies to agriculture.

During transformation and reforming of tax system of the Russian Federation it is necessary to provide the differential approach to the mechanism of taxation and tax regulation of activity of agricultural commodity producers, and to take into account features and specifics of this important branch of domestic economy.

\section{Theory}

As we have noticed, tax regulation is one of the effective instruments of state regulation of agricultural production. Now according to existing tax legislation agricultural commodity producers have the right to choose the most acceptable system of taxation. As an alternative to the general tax regime these categories of taxpayers have the right to use a 
special tax regime in the form of taxation system for agricultural commodity producers.

The critical analysis of practice of taxation of agricultural commodity producers in our country allows to draw conclusions on disproportion existence between growth rates of agricultural production and level of taxation of the territorial entities involved in this sphere. A conventional view is that export subsidies are inferior to output subsidies as a means of supporting farm prices. However, when there is an excess burden associated with general taxation measures, due to the distortions in markets arising from collection of taxes and any other costs associated with tax collections, export subsidies may be a component of the most efficient producer price support policy [5]. Fig. 1 shows data on dynamics of receipt of all tax payments to the budget system of the Russian Federation on activity of agricultural commodity producers of the Republic of Tatarstan from 2000 to 2012.

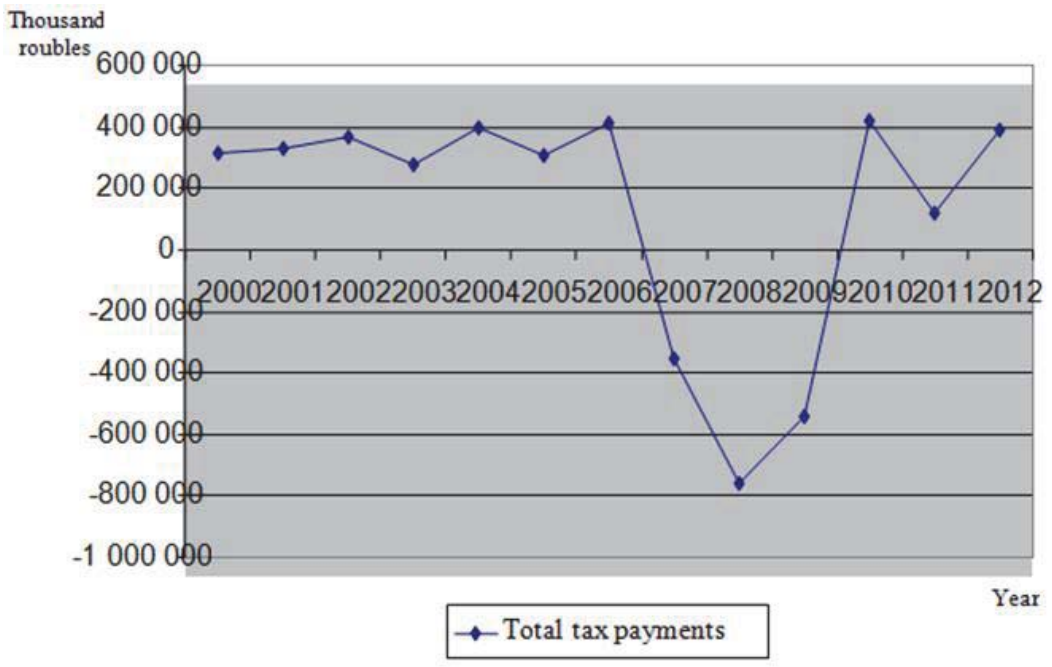

Fig. 1. Dynamics of receipt of all tax payments to the budget system of the Russian Federation on activity of agricultural commodity producers of the Republic of Tatarstan from 2000 to 2012., in thousand roubles.

These data demonstrate that steady reduction of receipt of tax payments from activity of agricultural commodity producers of the Republic of Tatarstan is observed since 2006, despite the positive tendency in 2011. Such indicators are the direct consequences of tax reforms carried out concerning the agricultural commodity producers directed on extension of the list of tax subsidies and decrease of tax burden of this branch. Boosting efficiency is a top priority in the development of any economic system. Creating a trouble-free Russia is impossible without innovative socio-economic development, effective implementation of demographic programs, creating quality jobs, effective social control, effective guarantees for the protection of property and fulfilling contracts, the competitiveness of key factors for running a business, the efficiency of state power, combating corruption and a number of other crucial factors [6]. Russia is not typical for the maximum reduction in the tax rate on income tax. Zero rate is used only in special areas of technical innovation, and subjects of the Russian Federation shall have the right to reduce the tax rate only to a certain level. This will not affect the formation of the tax revenues of the budget system, unlike indicators in developing countries [7].Speaking about the tax subsidies provided to agricultural commodity producers first of all it is necessary to cancel zero tax rate on income of the organizations which since 2013 is applied termlessly by this category of taxpayers, lowered tax rates on land tax and property tax of the organizations, and also removal of some types of property from structure of items of taxation on transport tax and the main thing is a voluntary order of transition to a special tax regime in the form of taxation system for agricultural commodity producers. The last feature makes this regime not quite popular among this category of taxpayers because its application doesn't give the chance to agricultural commodity producers to use tax deduction on value added tax and consequently to compensate this tax from the budget. The main problem of taxation of activity of agricultural commodity producers and their unwillingness to switch to payment of a unified agricultural tax are also connected with this circumstance.

It is obvious that the idea of carried-out tax reforms concerning activity of agricultural commodity producers is in decrease in their tax burden that first of all is directed on increase of growth rates of agricultural production, competitiveness of agricultural production and interest of the territorial entities involved in this branch, increase in gross domestic product. Review of tax incentives and research their effectiveness in different countries show that the 
developing countries in order to attract investment minimizes the corporate income tax rate, used tax holidays, investment credits, which reduced the tax revenues of the budget system [8], [9].

At the same time, the analysis of tax burden on the main types of economic activity in the Russian Federation, presented in Table 1, demonstrates its low level. In particular, considering the fact that agricultural production is a rather developed sector of economic activity and it participates actively in creation of gross domestic product, along with such branches as the extractive and manufacturing industries, construction and real estate activities. Развитие экономики сельского хозяйства исследовали такие авторы как Chen, Y., Chen, Y., Han, J.[10], Yuan, Q.M. , Feng, D., Liu, J. [11].

Data on dynamics of tax burden in the branch of agricultural production are presented in fig. 2.

Table 1. Tax burden by types of economic activity in Russia from 2006 to 2011 in percent

\begin{tabular}{|l|c|c|c|c|c|c|}
\hline Type of economic activity & $\begin{array}{l}2006 \\
\text { year }\end{array}$ & $\begin{array}{c}2007 \\
\text { year }\end{array}$ & $\begin{array}{c}2008 \\
\text { year }\end{array}$ & $\begin{array}{c}2009 \\
\text { year }\end{array}$ & $\begin{array}{c}2010 \\
\text { year }\end{array}$ & $\begin{array}{c}2011 \\
\text { year }\end{array}$ \\
\hline Extraction of minerals & 45,1 & 54,8 & 46,0 & 30,8 & 30,3 & 33,2 \\
\hline Other public utilities, social and personal services & 16,8 & 18,2 & 37,9 & 37,3 & 22,3 & 23,9 \\
\hline Real estate activities, rent and service & 18,2 & 29,5 & 30,0 & 23,7 & 19,7 & 22,2 \\
\hline Hotels and restaurants & 10,7 & 16,3 & 19,4 & 18,0 & 12,9 & 12,5 \\
\hline Construction & 11,9 & 15,9 & 14,5 & 16,2 & 11,3 & 12,2 \\
\hline Fishery, fish breeding & 13,7 & 15,3 & 13,7 & 12,6 & 9,3 & 7,6 \\
\hline Transport and communication & 11,7 & 15,0 & 13,3 & 13,0 & 9,8 & 9,7 \\
\hline Manufacturing industry & 7,2 & 10,5 & 9,6 & 9,3 & 7,2 & 7,1 \\
\hline Production and distribution of electricity, gas and water & 7,3 & 9,0 & 8,2 & 7,1 & 5,3 & 4,8 \\
\hline Agriculture, hunting and forestry & 5,5 & 8,7 & 8,0 & 7,4 & 4,2 & 3,6 \\
\hline Wholesale and retail trade, household services & 3,8 & 2,7 & 3,0 & 3,0 & 2,4 & 2,4 \\
\hline
\end{tabular}

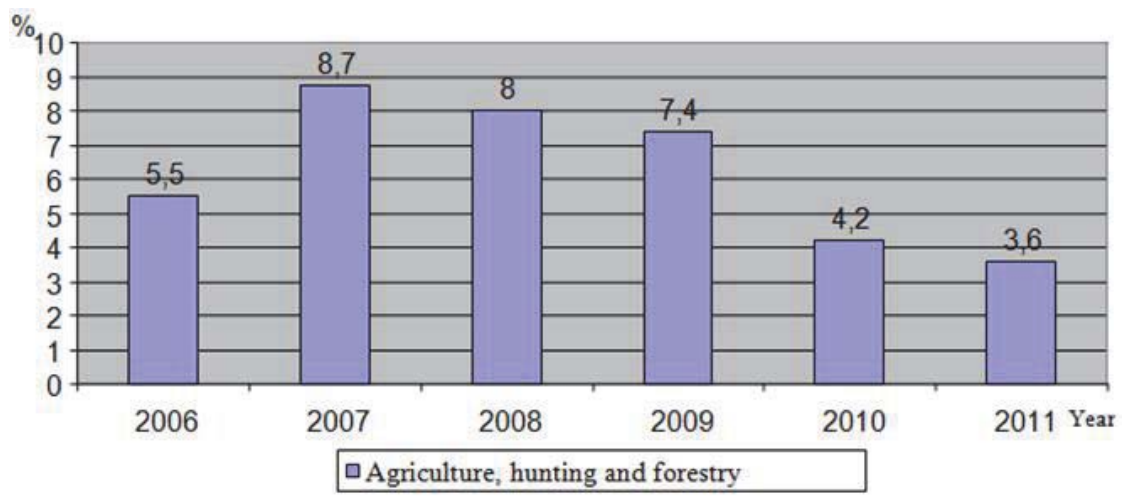

Fig. 2. Dynamics of tax burden in «agriculture, hunting and forestry» in Russia from 2006 to 2011, in percent.

Having compared fig. 1 and fig. 2, it is possible to note that exactly the period of the highest level of tax burden is characterized by the largest volume of compensation of value added tax from the budget by the agricultural producers applying a general regime of taxation.

On the other hand, at application of a special tax regime in the form of taxation system for agricultural commodity producers, relief from payment of a value added tax leads to increase in expenses on acquired material resources for its amount as the value added tax amount completely belongs to expenses that leads to production rise in price. In fact, there is a hidden transposition of value added tax to the ultimate consumer as it is a multiple stages tax and the exception of any stage of taxation leads to increase in the price of goods for the ultimate consumer at the stage of passing of agricultural raw materials through the enterprises of processing industry. Thus we come across the problem of formation of pricing. Consumers of agricultural products are organizations and entrepreneurs, applying a general regime of taxation, and who lose the right for value added tax deduction at buying goods from agricultural commodity producers who do not assess and set out it.

Следует также отметить, что the sector of agriculture needs protection for its critical role in responding to human needs as well as its vulnerability to various risks. This risk factor emanates from sector's high dependence to natural 
conditions and it is mainly this factor, which necessitates protection. Insurance is one way to cope with natural risks involved in agricultural activities [12]. This factor affects the tax burden on the industry "Agriculture, hunting and forestry" in Russia.

Comparison of advantages and disadvantages of transition to special tax regime in the form of system of taxation for agricultural commodity producers underlines that the question of expediency of application of the general or this special regime of taxation remains debatable.

\section{Results}

We draw the following conclusions and offer certain recommendations for the improvement of tax regulation of activity of agricultural commodity producers.

First of all, the taxation system for agricultural commodity producers has to emphasize not only fiscal function, but also regulating and stimulating functions which will allow to invest financial flows in agriculture for stimulation of development of agricultural sector.

In our opinion, now it is necessary to support new agricultural organizations. Applying general regime of taxation, such organizations bear high tax burden and thus they have no right to pass to system of taxation in the form of a unified agricultural tax for agricultural commodity producers in connection with non-performance of seventy-percentage criterion. Such position of the young agricultural organizations will be a negative and discouraging factor in development of agricultural sector.

It is necessary to use foreign experience of dating of agricultural production by fixing lower rate of a value added tax on agricultural production, and to count difference to compensation from the budget of repayment of obligations for other taxes and fees.

One of the directions of solving the problem of a value added tax may be the development of the lowered rates of this tax for buyers of agricultural production made by the organizations (payers of a unified agricultural tax), and also giving opportunities to consider an input value added tax at realization of goods (works, services), acquired at the organizations (payers of a unified agricultural tax) to the organizations applying the general system of taxation.

The alternative option is used to allow agricultural producers to fulfill tax obligations on a value added tax according to the order provided by Art. 145 of the Tax Code of the Russian Federation. In case the sales revenues don't exceed 2 million roubles for the calendar quarter, the agricultural producer is exempted from fulfillment of tax obligation for a value added tax. Value added tax paid to suppliers of goods, works, services used in the production activity, is considered as a part of expenses for taxation by a unified tax. If scales of activity exceed the established criterion, the organization becomes the payer of value added tax.

Taking into account seasonality of production of agricultural production it is necessary to fix legislatively calendar year as the tax period without use of the reporting periods on the main taxes paid by agricultural producers. Transfer of the moment of fulfilment of obligations on income tax of the organizations, a unified agricultural tax, corporate property tax, and also a value added tax by agricultural producers whose activity has seasonal nature, for the end of calendar year will allow to increase considerably financial stability, both certain economic territorial entities, and branch in general and it will allow to reduce derivation of own current assets by purchase of the material values necessary for carrying out agricultural works.

It is important to use the mechanism providing relief of owners from land tax, in case of carrying out a complex of actions directed on restoring soil fertility in the sum actually spent by them for this purposes.

We think, that regional authorities of territorial entities of the Russian Federation should work out and introduce the adjusting factor for each natural ecosystem which would correct taxable base on a unified agricultural tax towards reduction or increase depending on a climatic zone and structure of soils. And the agricultural organizations applying a general regime of taxation could correct taxable base on an income tax on this factor.

We believe, that the implementation of these proposals, will promote the formation of economically reasonable system of taxation of agriculture that finally, will allow to provide stable development of the branch and achievement of food security of the country. Thus, in our opinion, reforming of the system of taxation of activity of agricultural commodity producers, shouldn't be only in granting new tax privileges instead of liquidated ones, and can be aimed at providing such conditions of taxation which would take into account specifics of economic activity, including features of formation of financial flows in agriculture. 


\section{Conclusions}

On the basis of the research of theoretical issues and practical aspects of tax regulation of activity of agricultural commodity producers in the world and national practice and in particular in the Republic of Tatarstan it is possible to draw a conclusion that there are a lot of unresolved questions in this field. We consider, that it is necessary to carry out alternative calculations for the purpose of minimization of conditions of establishment of considerably differentiated relative levels of taxation in the process of working out methodical recommendations concerning questions of improvement of taxation of agricultural commodity producers. Extent of alignment for the agricultural enterprises of estimates of level of relative tax burden has to be the most important criterion in this case.

Besides, first of all, the system of taxation for agricultural commodity producers has to emphasize not only fiscal function, but also regulating and stimulating functions which will allow to invest financial flows in agriculture for stimulation of development of agricultural sector.

\section{References}

Wang D., Rao, X., Ying,Y. Development of agri-products traceability in main development agriculture region of the world // Nongye Gongcheng Xuebao/Transactions of the Chinese Society of Agricultural Engineering Volume 30. - Issue 8. - 2014. - pp.236-250.

Pillarisetti, J.R., Lawrey, P., Ahmad, A. Multifunctional agriculture, ecology and food security: international pespectives // Multifunctional agriculture, ecology and food security: international perspectives (Book) 2013 r. c.1-362.

Tsai, T.-H., Tu, K., Chiou, J.-R. Tariffs and Environmental Taxes in the Presence of Environmental R\&D // Environmental and Resource Economics - 2014. - Article in Press.

Orlova, M., Khafizova, A. The tax component of innovative activity assessment in the Russian Federation // Life Science Journal 2014. Issue 11. -pp.328-333.

Alston, J.M., Carter, C.A., Smith, V.H. Rationalizing agricultural export subsidies // American Journal of Agricultural Economics Volume 75. - Issue 4. - 1993. - pp.1000-1009.

Demyanova, O.V., Mahmutovich Valitov, S. A Multidimensional assessment of the efficiency of the Russian economy// World applied sciences journal Volume 25, Issue 5. - 2013. - pp.760-767.

Abbas, S.M.A.a, Klemm, A.b. A partial race to the bottom:Corporate tax developments in emerging and developing economies // International Tax and Public finance Volume 20, Issue 4. - 2013. - pp. 596-617.I

Van Parys, S.a, James, S.b. The effectiveness of tax incentives in attracting investment: Panel data evidence from the CFA Franc zone I/ International Tax and Public finance Volume 17, Issue 4. - 2010. - pp. 400-429.

Klemm, A. Causes, benefits, and risks of business tax incentives // International Tax and Public finance Volume 17, Issue 3. - 2010. pp.315-336.

Chen, Y., Chen, Y., Han, J. Correlation analysis on water resources utilization and the sustainable development of economy in Minqin of Gansu Province // Journal of Chemical and Pharmaceutical Research Volume 6, Issue 4. - 2014. - pp.157-161.

Yuan, Q.M. , Feng, D., Liu, J. Analysis of the correlation effect of the development of Tianjin marine economy and land economy /I Conference paper Advanced Materials Research. - 2014. - pp.648-651.

Gulcubuk, B. , Gunes, E. Applicable agricultural insurance models at the rural area: A case study from Turkey // Scientific Research and Essays Volume 5, Issue 9. - 2010. - pp.837-844. 